Journal of Clinical Investigation

Vol. 41, No. 5,1962

\title{
RESTORATION OF WATER DIURESIS IN ADDISONIAN PATIENTS BY EXPANSION OF THE VOLUME OF EXTRACELLULAR FLUID *
}

\author{
By JOHN R. GILL, JR., DONALD S. GANN † AND FREDERIC C. BARTTER with the \\ ASSISTANCE OF ISABELLE M. AMBROSE and GEORGE W. SMITH, II
}

(From the Clinical Endocrinology Branch, National Heart Institute, Bethesda, Md.)

(Submitted for publication October 6, 1961 ; accepted January 18, 1962)

Although the inability of patients with Addison's disease to excrete a water load is well known, the nature of this defect remains obscure. The effects of changing glomerular filtration rate (GFR) and solute excretion $\left(\mathrm{U}_{\mathrm{osm}} \mathrm{V}\right)$ on water excretion in patients with adrenal insufficiency have recently been described (1). While an increase in these two variables leads to an increase in the excretion of water, the improvement is very small compared with that seen with carbohydrate-active steroids.

In healthy persons expansion of the volume of extracellular fluid may increase the rate of excretion of solute-free water $\left(\mathrm{C}_{\mathrm{H}_{2} \mathrm{O}}\right)(2,3)$. In patients with Addison's disease, when replacement therapy is stopped, the increase in urinary sodium excretion leads to a depletion of body fluids, and continues despite this depletion. It is possible that depletion of the volume of extracellular fluid (ECF) could limit the rate at which water is excreted. These experiments were designed to explore the effects of contraction and expansion of the volume of ECF on water excretion in adrenal insufficiency.

Experiments on effects of increases in solute excretion on $\mathrm{C}_{\mathrm{H}_{2} \mathrm{O}}$ are also presented to clarify further the mechanism whereby expansion of volume corrects the impairment in excretion of water. The effects of treatment with cortisol are included for comparison.

\section{METHODS}

The four subjects of this study ranged in age from 36 to 61 years. All had the clinical features of Addison's disease, and urinary 17-hydroxycorticoids which were below normal and did not increase with adrenocorticotropin (40 $\mathrm{U}$ given intravenously over 8 hours, each day for 5 days). They remained on an air-conditioned metabolic ward and took a normal diet, which was well toler-

* Presented at the National Meeting of The American Federation for Clinical Research, Atlantic City, N. J., May 3, 1959.

$\dagger$ Present address: Dept. of Surgery, Western Reserve University, Cleveland, Ohio. ated even when they were not receiving treatment. Body weight, determined with metabolic scales daily on arising, was used as a gross approximation of changes in the volume of body fluids. The patients were studied under the following conditions: $a$ ) untreated for 4 to 20 days; $b$ ) after expansion of ECF with physiologic saline ( 0.9 per cent) ; ${ }^{1} c$ ) after expansion of ECF with saline and treatment with cortisol acetate, $25 \mathrm{mg}$ per day for 3 to 4 days. Saline was given intravenously, beginning 1 to 3 days before a given study. The amount varied from 2 to $5 \mathrm{~L}$ per day, as dosage was increased until the body weight indicated that net fluid volume had returned to values comparable with those observed during treatment with cortisol. When body weight on the day of study indicated that the saline given on the previous day had not been retained, an additional 1.5 to $2.5 \mathrm{~L}$ was infused before the study.

All studies were done in the morning on fasting patients, after they had received a "priming" water load ( $200 \mathrm{ml}$ given orally 1 and 2 hours before study). As a water load, solutions containing 4 per cent fructose were infused for five clearance periods, followed immediately by solutions of physiologic saline which were continued until urine flow reached a peak. Solutions containing 4 per cent mannitol were infused on a separate day under conditions $a$ and $b$ only. All solutions contained inulin, and were delivered by a Bowman constant infusion pump at $15 \mathrm{ml}$ per min, with the patient recumbent. Urine was collected by indwelling bladder catheter, with air washes at the end of each 20-minute period; venous blood was obtained at mid-period through an indwelling Cournand needle. The clearance of alkali-stable inulin was measured by the method of Walser, Davidson and Orloff (5), serum and urine sodium by internal standard flame photometer, and osmolality of serum and urine by Bowman osmometer (6). $\mathrm{C}_{\mathrm{H}_{2} \mathrm{O}}$ was computed from the formula: $\mathrm{C}_{\mathrm{H}_{2} \mathrm{O}}=\mathrm{V}-\left(\mathrm{U}_{\mathrm{osm}} \mathrm{V} / \mathrm{P}_{\mathrm{osm}}\right)$ with a negative value to be understood as $\mathrm{T}^{\mathrm{c}} \mathrm{H}_{2} \mathrm{O}$ (7). Whereas serum was analyzed, the osmolality of serum has been designated in the tables as $P_{o s m}$, in keeping with current usage.

\section{RESULTS}

I. Effect on $C_{\mathrm{H}_{2} \mathrm{O}}$ of acute expansion with saline (Table I, Figure 1). When treatment was stopped

1 Expansion of ECF was also produced with hyperoncotic serum albumin in two patients (4). Although the albumin improved $\mathrm{C}_{\mathrm{H}_{2} \mathrm{O}}$, it was not so effective as saline. 
TABLE I

Effect of infusion of fructose and of physiologic saline on $\mathrm{C}_{\mathrm{H}_{2} \mathrm{O}}$ in patients off treatment

\begin{tabular}{|c|c|c|c|c|c|c|c|c|c|c|c|}
\hline Patient & Weight & $\begin{array}{c}\text { Serum } \\
\mathrm{Na}\end{array}$ & Infusate & Period & $\begin{array}{l}\text { Urinary } \\
\text { volume }\end{array}$ & $P_{\text {osm }}$ & Uosm & $\mathrm{C}_{\mathrm{H}_{2} \mathrm{O}}$ & $\mathrm{UNaV}_{\mathrm{Na}}$ & UosmV & $\mathrm{C}_{\text {In }}$ \\
\hline A.B. & $\begin{array}{c}\mathrm{kg} \\
46.9\end{array}$ & $\begin{array}{c}m E q / L \\
137\end{array}$ & $\begin{array}{l}\text { Fructose } \\
\text { Salinet }\end{array}$ & $\begin{array}{c}1 \\
3 \\
5^{*} \\
11\end{array}$ & $\begin{array}{c}m l / m i n \\
0.7 \\
3.7 \\
5.3 \\
7.1\end{array}$ & $\begin{array}{c}m O s m / L \\
272 \\
266 \\
262 \\
262\end{array}$ & $\begin{array}{c}m O s m / L \\
430 \\
171 \\
104 \\
85\end{array}$ & $\begin{array}{c}\mathrm{ml} / \mathrm{min} \\
-0.4 \\
1.3 \\
3.2 \\
4.8\end{array}$ & $\begin{array}{c}\mu E q / \min \\
81 \\
160 \\
126 \\
224\end{array}$ & $\begin{array}{c}\mu O s m / m i n \\
301 \\
633 \\
551 \\
603\end{array}$ & $\begin{array}{c}m l / m i n \\
41 \\
48 \\
47 \\
51\end{array}$ \\
\hline J.D. & 63.4 & 133 & $\begin{array}{l}\text { Fructose } \\
\text { Saline† }\end{array}$ & $\begin{array}{c}1 \\
3^{*} \\
5 \\
14\end{array}$ & $\begin{array}{l}0.9 \\
2.0 \\
1.8 \\
8.0\end{array}$ & $\begin{array}{l}254 \\
252 \\
246 \\
251\end{array}$ & $\begin{array}{l}558 \\
221 \\
314 \\
109\end{array}$ & $\begin{array}{r}-1.1 \\
0.3 \\
-0.5 \\
4.5\end{array}$ & $\begin{array}{r}35 \\
72 \\
86 \\
240\end{array}$ & $\begin{array}{l}502 \\
442 \\
565 \\
872\end{array}$ & \\
\hline L.G. & 89.9 & 124 & $\begin{array}{l}\text { Fructose } \\
\text { Saline† }\end{array}$ & $\begin{array}{l}1 \\
3^{*} \\
5 \\
12\end{array}$ & $\begin{array}{r}1.2 \\
5.7 \\
1.4 \\
13.7\end{array}$ & $\begin{array}{l}232 \\
232 \\
231 \\
237\end{array}$ & $\begin{array}{r}449 \\
133 \\
445 \\
44\end{array}$ & $\begin{array}{r}-1.1 \\
2.4 \\
-1.3 \\
11.1\end{array}$ & $\begin{array}{r}49 \\
133 \\
96 \\
167\end{array}$ & $\begin{array}{l}539 \\
758 \\
623 \\
603\end{array}$ & $\begin{array}{l}77 \\
80 \\
74 \\
92\end{array}$ \\
\hline M.T. & 38.8 & 138 & $\begin{array}{l}\text { Fructose } \\
\text { Salinet }\end{array}$ & $\begin{array}{l}1 \\
3 \\
5^{*} \\
9\end{array}$ & $\begin{array}{l}1.4 \\
4.6 \\
7.6 \\
9.8\end{array}$ & $\begin{array}{l}266 \\
262 \\
261 \\
261\end{array}$ & $\begin{array}{l}535 \\
293 \\
151 \\
116\end{array}$ & $\begin{array}{r}-1.4 \\
-0.5 \\
3.2 \\
5.5\end{array}$ & & $\begin{array}{r}749 \\
1,348 \\
1,148 \\
1,137\end{array}$ & $\begin{array}{l}60 \\
63 \\
67\end{array}$ \\
\hline M.T. & 37.6 & 138 & Fructose & $\begin{array}{l}1 \\
3^{*} \\
5\end{array}$ & $\begin{array}{l}0.4 \\
5.3 \\
2.4\end{array}$ & $\begin{array}{l}268 \\
260 \\
253\end{array}$ & $\begin{array}{l}498 \\
176 \\
433\end{array}$ & $\begin{array}{r}-0.3 \\
1.7 \\
-1.7\end{array}$ & & $\begin{array}{r}199 \\
933 \\
1,039\end{array}$ & $\begin{array}{l}48 \\
56\end{array}$ \\
\hline
\end{tabular}

* Maximal value obtained during infusion of fructose.

† Only the maximal value during the infusion of saline is given.

$\ddagger$ Second study after additional loss of weight.

from 4 to as long as 20 days (L.G.), the patients lost from 1.6 to $5.3 \mathrm{~kg}$ in weight, and serum $\mathrm{Na}$ concentration fell. Despite this initial hypotonicity of the ECF, and the further effect of the "priming" load of water, the osmolality of the initial urine specimens, always greater than that of the serum, ranged from 430 to $558 \mathrm{mOsm}$ per $\mathrm{L}$ (Table I). During the infusions of fructose, the volume of urine increased and urinary osmolality decreased, with $\mathrm{C}_{\mathrm{H}_{2} \mathrm{O}}$ rising to maximal values which ranged from 0.3 to $3.2 \mathrm{ml}$ per minute (Figures 1 and 2, Table I). Despite continued infusion of fructose, with further decreases in serum osmolality, urine osmolality then rose to 314,445 , and $433 \mathrm{mOsm}$ per L in J.D., L.G., and M.T., respectively, and $\mathrm{C}_{\mathrm{H}_{2} \mathrm{O}}$ again became negative (period 5, Figures 1 and 2, and Table I). When the infusate was changed from fructose to isotonic saline, urine volume rose in all patients to reach values which exceeded those seen during administration of fructose (Figure 1, Table I). Minimal urinary osmolalities (range, 44 to $116 \mathrm{mOsm}$ per $\mathrm{L})$, were generally less than the minimal values observed during infusion of fructose (range, 104 to 221 ). $\mathrm{C}_{\mathrm{H}_{2} \mathrm{O}}$, which had ranged from 0.3 to 3.2 $\mathrm{ml}$ per minute, rose in all cases, to reach values ranging from $4.5 \mathrm{ml}$ per minute in J.D. to as high as 11.1 in L.G. (Table I and Figure 1). The increase in $\mathrm{C}_{\mathrm{H}_{2} \mathrm{O}}$ was not associated with an increase in $\mathrm{U}_{\mathrm{osm}} \mathrm{V}$ except in Patient J.D. (Figure 1, Table I). The GFR was either essentially unchanged by the infusion of saline (A.B., M.T.), or somewhat higher at the end of it (L.G., Figure 1).

II. Effect on $C_{\mathrm{H}_{2} \mathrm{O}}$ of sustained expansion with saline (Table II, Figure 2). When the patients had been treated with large quantities of isotonic saline given intravenously, the weight loss that follows discontinuation of treatment (Table I) was minimized (Table II). Under these circumstances fructose produced rises in urine flow and falls in urinary osmolality which were much greater than those produced by fructose in the depleted state and, indeed, were comparable with those produced by saline in the depleted state. $\mathrm{C}_{\mathrm{H}_{2} \mathrm{O}}$, which had ranged from 0.3 to $3.2 \mathrm{ml}$ per minute in the control studies, rose in the expanded state to values ranging from 4.4 to $13.4 \mathrm{ml}$ per minute (Figure 2, Tables I and II). In contrast to the findings in the depleted state, $\mathrm{C}_{\mathrm{H}_{2} \mathrm{O}}$ was now maintained throughout the administration of fructose in all 


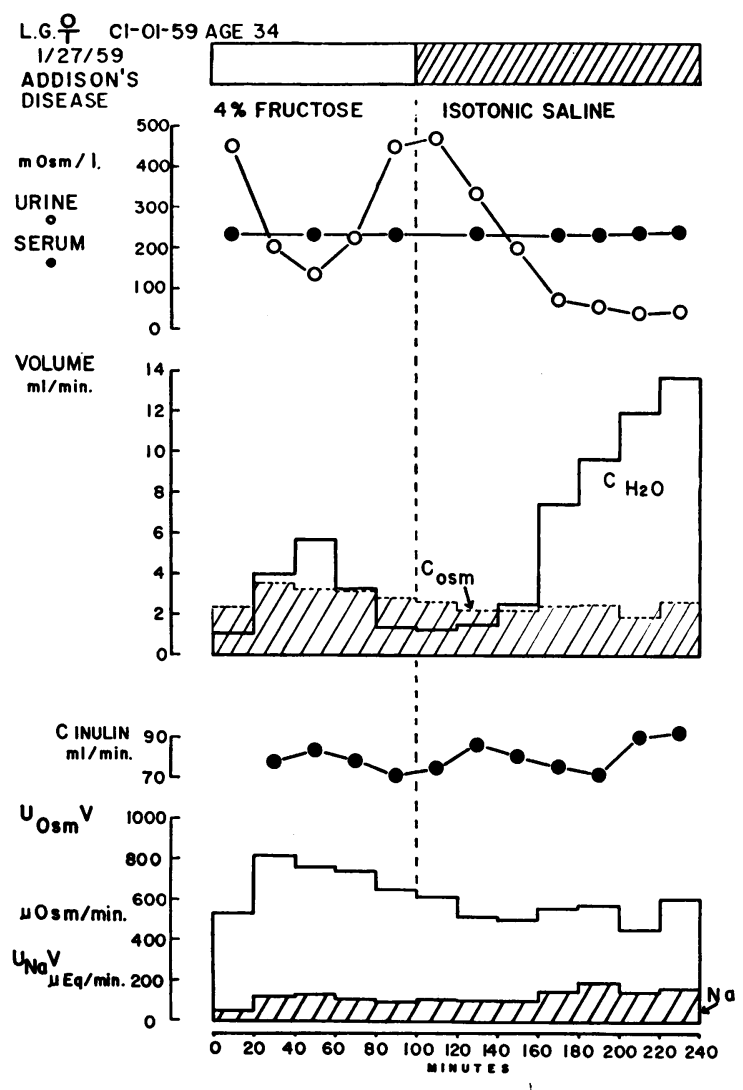

Fig. 1. Changes in SERUM and URINARY osmolality, $\mathrm{C}_{\mathrm{H}_{2} \mathrm{O}}, \mathrm{C}_{\mathrm{osm}}, \mathrm{C}_{\mathrm{In}}, \mathrm{U}_{\mathrm{Osm}} \mathrm{V}$, AND $\mathrm{U}_{\mathrm{Na}} \mathrm{V}$ WHEN aN INFUSION OF FRUCTOSE IS FOLLOWED BY AN INFUSION OF SALINE. Note that urinary osmolality rises while fructose is still being infused. The increase in $\mathrm{C}_{\mathrm{H}_{2} \mathrm{O}}$ during the infusion of saline occurs without an increase in solute excretion, and before the increase in GFR.

patients (Figure 2); it did not rise further when the infusate was changed to saline, except in $\mathrm{Pa}$ tient A.B. (Table II). The higher $\mathrm{C}_{\mathrm{H}_{2} \mathrm{O}}$ during the infusion of fructose in the expanded state was usually associated with a greater excretion of sodium and total solute than was that seen in the depleted state, but it was also observed with a $\mathrm{U}_{\mathrm{Osm}} \mathrm{V}$ no greater than that in the depleted state (compare L.G. and M.T. in Tables I and II). The GFR was higher in every patient during sustained expansion (Table II).

III. Effect on $C_{\mathrm{H}_{2} \mathrm{O}}$ of increasing solute excretion in the depleted and expanded states (Table III, Figure 3). Three of the patients received 4 per cent mannitol intravenously while ECF was contracted, and again while it was expanded with saline. In both states mannitol induced an increase in urine volume and a decrease in urinary osmolality except in L.G., expanded (Table III). The maximal values for $\mathrm{C}_{\mathrm{H}_{2} \mathrm{O}}$ with mannitol ranged from 1.5 to $2.6 \mathrm{ml}$ per minute in the depleted state, and from 3.1 to $5.5 \mathrm{ml}$ per minute in the expanded state.

In the depleted state, $\mathrm{C}_{\mathrm{H}_{2} \mathrm{O}}$ reached maximal values in the third to the fifth period, then fell, together with urine flow, without increase in serum osmolality and despite continued rise in solute excretion (Table III). In A.B. and L.G. the maximal values for $\mathrm{C}_{\mathrm{H}_{2} \mathrm{O}}$ attained with mannitol ( 1.7 and $1.5 \mathrm{ml}$ per minute respectively) were less than those observed with either fructose (3.2 and $2.4 \mathrm{ml}$ per minute, respectively) or saline ( 4.8 and $11.1 \mathrm{ml}$ per minute, respectively) in the depleted state. The excretion of solute (including $\mathrm{Na}$ ) with mannitol was greater in the depleted state than that with either fructose or saline in a comparably depleted state (compare Tables I and III), and greater than that with fructose in the expanded state (compare Tables II and III).

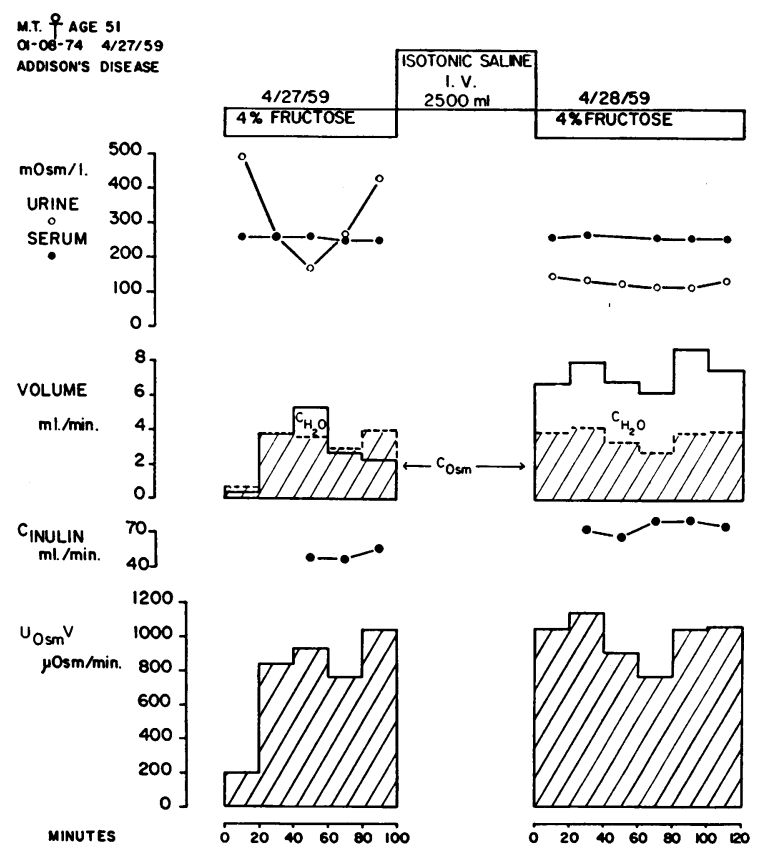

Fig. 2. Serum and urinary osmolalities, $\mathrm{C}_{\mathrm{H}_{2} \mathrm{O}}, \mathrm{C}_{\mathrm{O}} \mathrm{m}$, $\mathrm{C}_{\text {In, AND }}$ UosmV, DURING FRUCTOSE INFUSION, BEFORE AND AFTER EXPANSION WITH SALINE. After expansion, minimal urinary osmolality and $\mathrm{C}_{\mathrm{H}_{2} \mathrm{O}}$ are maintained throughout the infusion of fructose. The increase in $\mathrm{C}_{\mathrm{H}_{2} \mathrm{O}}$ is not associated with an increase in solute excretion. 
TABLE II

Effect of infusion of fructose and of physiologic saline on $C_{\mathrm{H}_{2} \mathrm{O}}$ in patients with ECF expanded by saline

\begin{tabular}{|c|c|c|c|c|c|c|c|c|c|c|}
\hline Patient & Weight & $\underset{\mathrm{Na}}{\text { Serum }}$ & Infusate & $\begin{array}{l}\text { Urinary } \\
\text { volume }\end{array}$ & $P_{\text {osm }}$ & Uosm & $\mathrm{C}_{\mathrm{H}_{2} \mathrm{O}^{*}}$ & $\mathrm{U}_{\mathrm{NaV}}$ & UosmV & $\mathrm{C}_{\text {In }}$ \\
\hline A.B. & $\begin{array}{c}k g \\
49.0\end{array}$ & $\begin{array}{c}m E q / L \\
136\end{array}$ & $\begin{array}{l}\text { Fructose } \\
\text { Saline }\end{array}$ & $\begin{array}{c}\mathrm{ml} / \mathrm{min} \\
7.8 \\
14.3\end{array}$ & $\begin{array}{c}m O s m / L \\
256 \\
260\end{array}$ & $\begin{array}{c}m O s m / L \\
111 \\
111\end{array}$ & $\begin{array}{c}m l / m i n \\
4.4 \\
8.2\end{array}$ & $\begin{array}{c}\mu E q / \min \\
265 \\
800\end{array}$ & $\begin{array}{c}\mu O s m / m i n \\
866 \\
1,587\end{array}$ & $\begin{array}{c}m l / m i n \\
59 \\
69\end{array}$ \\
\hline J.D. & 68.0 & 135 & $\begin{array}{l}\text { Fructose } \\
\text { Saline }\end{array}$ & $\begin{array}{l}11.8 \\
11.8\end{array}$ & $\begin{array}{l}253 \\
256\end{array}$ & $\begin{array}{l}108 \\
109\end{array}$ & $\begin{array}{l}6.7 \\
6.8\end{array}$ & $\begin{array}{l}477 \\
515\end{array}$ & $\begin{array}{l}1,274 \\
1,286\end{array}$ & $\begin{array}{l}60 \\
61\end{array}$ \\
\hline L.G. & 93.2 & 138 & $\begin{array}{l}\text { Fructose } \\
\text { Saline }\end{array}$ & $\begin{array}{l}17.0 \\
11.8\end{array}$ & $\begin{array}{l}260 \\
259\end{array}$ & $\begin{array}{l}55 \\
72\end{array}$ & $\begin{array}{r}13.4 \\
8.5\end{array}$ & $\begin{array}{l}258 \\
330\end{array}$ & $\begin{array}{l}935 \\
850\end{array}$ & $\begin{array}{l}88 \\
76\end{array}$ \\
\hline M.T. & $38.8 \dagger$ & 140 & Fructose & 8.8 & 263 & 119 & 4.8 & & 1,047 & 79 \\
\hline
\end{tabular}

* Maximal value obtained during infusion of each solution.

$\dagger$ Morning body weight before infusion of $2.5 \mathrm{~L}$ of saline.

In the expanded state, $\mathrm{C}_{\mathrm{H}_{2} \mathrm{O}}$ continued throughout the administration of mannitol, except in $\mathrm{Pa}$ tient L. G., and was associated with the highest rates of sodium and total solute excretion observed in these studies (Figure 3 ). Nevertheless, the maximal values for $\mathrm{C}_{\mathrm{H}_{2} \mathrm{O}}$ of $3.2,5.5$, and 3.1 $\mathrm{ml}$ per minute in A.B., J.D., and L.G., respectively, while greater than those seen with either mannitol or fructose in the depleted state, were less (except in J.D.) than those seen with saline in the depleted state $(4.8,4.5$, and $11.1 \mathrm{ml}$ per minute, respectively) or with fructose in the expanded state $(4.4,6.7$, and $13.4 \mathrm{ml}$ per minute, respectively ; Figure 3, Tables I, II, and III). In both states, the changes in GFR with infusion of mannitol were small and variable. The effects of mannitol on $\mathrm{C}_{\mathrm{H}_{2} \mathrm{O}}, \mathrm{GFR}, \mathrm{U}_{\mathrm{Na}} \mathrm{V}$ and $\mathrm{U}_{\mathrm{Osm}} \mathrm{V}$ are summarized and contrasted with those of fructose in Figure 3.

$I V$. Effect on $C_{\mathrm{H}_{2} \mathrm{O}}$ of sustained expansion with saline and treatment with cortisol (Table IV). When the patients had been treated with isotonic saline, given intravenously, and cortisol, their body weights were comparable with, or greater than, those seen with saline alone (compare Tables II

TABLE III

Effect of infusion of mannitol on $\mathrm{C}_{\mathrm{H}_{2} \mathrm{O}}$ in patients with ECF volume depleted before and during sustained expansion with saline

\begin{tabular}{|c|c|c|c|c|c|c|c|c|c|c|c|}
\hline Patient & State & Weight & $\underset{\mathrm{Na}}{\text { Serum }}$ & Period & $\begin{array}{l}\text { Urinary } \\
\text { volume }\end{array}$ & Posm & Uosm & $\mathrm{CH}_{2} \mathrm{O}$ & $\mathrm{UNa}_{\mathrm{Na}} \mathrm{V}$ & UosmV & $\mathrm{C}_{\text {In }}$ \\
\hline & & $k g$ & $m E q / L$ & & $m l / m i n$ & $m O s m / L$ & $m O s m / L$ & $m l / m i n$ & $\mu E q / \min$ & $\mu O s m / \min$ & $\mathrm{ml} / \mathrm{min}$ \\
\hline \multirow[t]{2}{*}{ A.B. } & Depleted & 47.3 & 134 & $\begin{array}{l}1 \\
5^{*} \\
6\end{array}$ & $\begin{array}{l}2.1 \\
7.5 \\
7.1\end{array}$ & $\begin{array}{l}273 \\
272 \\
269\end{array}$ & $\begin{array}{l}521 \\
211 \\
245\end{array}$ & $\begin{array}{r}-1.9 \\
1.7 \\
0.6\end{array}$ & $\begin{array}{l}313 \\
283 \\
416\end{array}$ & $\begin{array}{l}1,094 \\
1,582 \\
1,740\end{array}$ & $\begin{array}{l}40 \\
43 \\
30\end{array}$ \\
\hline & Expanded & 47.6 & 138 & $\begin{array}{l}1 \\
6^{*}\end{array}$ & $\begin{array}{r}1.6 \\
12.0\end{array}$ & $\begin{array}{l}269 \\
270\end{array}$ & $\begin{array}{l}510 \\
199\end{array}$ & $\begin{array}{r}-1.4 \\
3.2\end{array}$ & $\begin{array}{l}198 \\
480\end{array}$ & $\begin{array}{r}816 \\
2,388\end{array}$ & $\begin{array}{l}51 \\
47\end{array}$ \\
\hline \multirow[t]{2}{*}{ J.D. } & Depleted & 65.6 & 129 & $\begin{array}{l}1 \\
4^{*} \\
5\end{array}$ & $\begin{array}{r}2.2 \\
11.1 \\
9.5\end{array}$ & $\begin{array}{l}267 \\
265 \\
266\end{array}$ & $\begin{array}{l}234 \\
204 \\
241\end{array}$ & $\begin{array}{l}0.3 \\
2.6 \\
0.9\end{array}$ & $\begin{array}{r}70 \\
272 \\
270\end{array}$ & $\begin{array}{r}515 \\
2,264 \\
2,290\end{array}$ & $\begin{array}{l}69 \\
77 \\
66\end{array}$ \\
\hline & Expanded & 69.1 & 143 & $\begin{array}{l}1 \\
4^{*}\end{array}$ & $\begin{array}{r}6.9 \\
18.0\end{array}$ & $\begin{array}{l}264 \\
261\end{array}$ & $\begin{array}{l}234 \\
181\end{array}$ & $\begin{array}{l}0.8 \\
5.5\end{array}$ & $\begin{array}{r}532 \\
1,010\end{array}$ & $\begin{array}{l}1,615 \\
3,258\end{array}$ & $\begin{array}{r}137 \\
95\end{array}$ \\
\hline \multirow[t]{2}{*}{ L.G. } & Depleted & 89.4 & 125 & $\begin{array}{l}1 \\
3^{*} \\
5\end{array}$ & $\begin{array}{r}2.6 \\
10.8 \\
9.7\end{array}$ & $\begin{array}{l}244 \\
244 \\
242\end{array}$ & $\begin{array}{l}354 \\
209 \\
278\end{array}$ & $\begin{array}{r}-1.2 \\
1.5 \\
-1.4\end{array}$ & $\begin{array}{l}110 \\
430 \\
388\end{array}$ & $\begin{array}{r}920 \\
2,257 \\
2,697\end{array}$ & $\begin{array}{r}105 \\
93 \\
90\end{array}$ \\
\hline & Expanded & 92.4 & 137 & $\begin{array}{l}1 \\
4^{*} \\
6\end{array}$ & $\begin{array}{r}5.5 \\
10.8 \\
7.5\end{array}$ & $\begin{array}{l}266 \\
266 \\
271\end{array}$ & $\begin{array}{l}167 \\
193 \\
296\end{array}$ & $\begin{array}{r}2.0 \\
3.1 \\
-0.7\end{array}$ & $\begin{array}{l}147 \\
272 \\
214\end{array}$ & $\begin{array}{r}918 \\
2,084 \\
2,220\end{array}$ & \\
\hline
\end{tabular}

* The period of maximal $\mathrm{C}_{\mathrm{H}_{2} \mathrm{O}}$. 


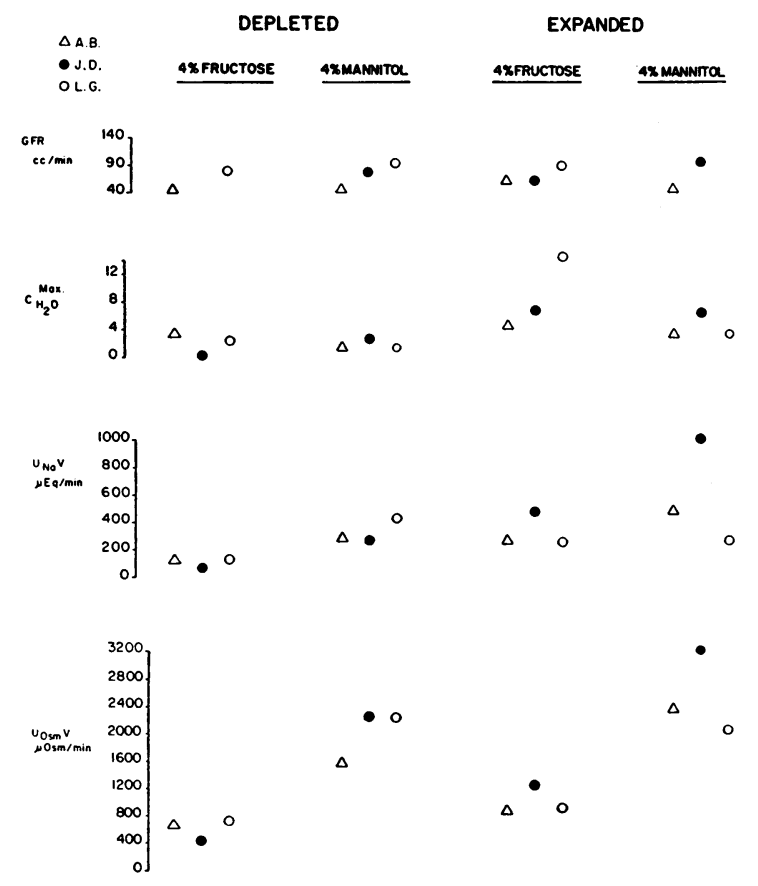

Fig. 3. GFR, $\mathrm{C}_{\mathrm{H}_{2} \mathrm{O}}, \mathrm{U}_{\mathrm{Na}} \mathrm{V}$, AND $\mathrm{U}_{\mathrm{osm}} \mathrm{V}$ DURING INFUSIONS OF FRUCTOSE AND OF MANNITOL IN THE DEPLETED AND EXPANDED STATES. Note that the large changes in $\mathrm{U}_{\mathrm{Osm}} \mathrm{V}$ and $\mathrm{U}_{\mathrm{Na}} \mathrm{V}$ produced by mannitol do not markedly change $\mathrm{C}_{\mathrm{H}_{2} \mathrm{O}}$.

and IV). In general, in the presence of cortisol, infusions of fructose produced urine flow and $\mathrm{C}_{\mathrm{H}_{2} \mathrm{O}}$ as great, and urinary osmolality as low, as those produced in the absence of cortisol (Tables II and IV). When the infusate was changed to isotonic saline, $\mathrm{C}_{\mathrm{H}_{2} \mathrm{O}}$ showed a further modest increase, except in L.G. The maximal value with saline was higher during treatment with cortisol only in J.D. (15.4 as opposed to $6.8 \mathrm{ml}$ per minute) ; it was essentially the same in A.B. and L.G. (9.0 and 9.2 as opposed to 8.2 and $8.5 \mathrm{ml}$ per minute, respectively); comparable data are not available for M.T., off cortisol. The higher $\mathrm{C}_{\mathrm{H}_{2} \mathrm{O}}$ observed in J. D. with cortisol was associated with a twofold increase in GFR and a 50 per cent decrease in $\mathrm{U}_{\mathrm{Na}} \mathrm{V}$ (compare Tables II and IV).

While sodium excretion was generally less during treatment with cortisol, total solute excretion was similar to that seen during sustained expansion without cortisol. GFR was comparable in Patients A.B. and M.T. and higher in J.D. and L.G.

\section{DISCUSSION}

Without treatment, all the Addisonian patients in this study excreted excessive quantities of salt, lost weight, and demonstrated a very limited ability to excrete a water load. Yet, when the infusions of fructose were followed immediately with infusions of physiologic saline, the excretion of solute-free water markedly increased in all the patients (Table I, Figure 1). It is not likely that this rise in $\mathrm{C}_{\mathrm{H}_{2} \mathrm{O}}$ during the infusion of saline was a delayed response to the water load, since $\mathrm{C}_{\mathbf{H}_{2} \mathrm{O}}$ had, in three subjects, risen to maximal values and then fallen to negative values before the infusate was changed from fructose to saline (Figures 1 and 2, Table I).

By administration of large quantities of salt intravenously, it was possible to avoid the loss of weight and the depletion of extracellular fluid that

TABLE IV

Effect of infusion of fructose and of physiologic saline on $C_{\mathrm{H}_{2} \mathrm{O}}$ in patients with ECF expanded during treatment with cortisol

\begin{tabular}{|c|c|c|c|c|c|c|c|c|c|c|}
\hline Patient & Weight & $\underset{\mathrm{Na}}{\text { Serum }}$ & Infusate & $\begin{array}{l}\text { Urinary } \\
\text { volume }\end{array}$ & Posm & Uosm & $\mathrm{C}_{\mathrm{H}_{2} \mathrm{O}^{*}}$ & $\mathrm{U}_{\mathrm{Na}} \mathrm{V}$ & $\mathrm{U}_{\mathrm{Osm}} \mathrm{V}$ & $\mathrm{C}_{\mathbf{I n}}$ \\
\hline A.B. & $\begin{array}{c}k g \\
48.5\end{array}$ & $\begin{array}{c}m E q / L \\
142\end{array}$ & $\begin{array}{l}\text { Fructose } \\
\text { Saline }\end{array}$ & $\begin{array}{l}\mathrm{ml} / \mathrm{min} \\
14.0 \\
13.0\end{array}$ & $\begin{array}{c}m O s m / L \\
289 \\
290\end{array}$ & $\begin{array}{c}m O s m / L \\
112 \\
89\end{array}$ & $\begin{array}{l}m l / m i n \\
8.6 \\
9.0\end{array}$ & $\begin{array}{c}\mu E q / \min \\
522 \\
427\end{array}$ & $\begin{array}{c}\mu O s m / m i n \\
1,568 \\
1,157\end{array}$ & $\begin{array}{c}m l / m i n \\
63 \\
66\end{array}$ \\
\hline J.D. & 68.7 & & $\begin{array}{l}\text { Fructose } \\
\text { Saline }\end{array}$ & $\begin{array}{l}17.4 \\
18.2\end{array}$ & $\begin{array}{l}265 \\
265\end{array}$ & $\begin{array}{l}50 \\
40\end{array}$ & $\begin{array}{l}14.0 \\
15.4\end{array}$ & 222 & $\begin{array}{l}870 \\
728\end{array}$ & $\begin{array}{l}121 \\
122\end{array}$ \\
\hline L.G. & 94.6 & & $\begin{array}{l}\text { Fructose } \\
\text { Saline }\end{array}$ & $\begin{array}{l}14.2 \\
12.6\end{array}$ & $\begin{array}{l}267 \\
269\end{array}$ & $\begin{array}{l}59 \\
73\end{array}$ & $\begin{array}{r}11.1 \\
9.2\end{array}$ & $\begin{array}{l}198 \\
169\end{array}$ & $\begin{array}{l}838 \\
920\end{array}$ & $\begin{array}{l}125 \\
118\end{array}$ \\
\hline M.T. & 40.9 & 143 & $\begin{array}{l}\text { Fructose } \\
\text { Saline }\end{array}$ & $\begin{array}{l}13.5 \\
13.9\end{array}$ & $\begin{array}{l}278 \\
277\end{array}$ & $\begin{array}{l}69 \\
56\end{array}$ & $\begin{array}{l}10.2 \\
11.1\end{array}$ & 246 & $\begin{array}{l}932 \\
778\end{array}$ & $\begin{array}{l}67 \\
69\end{array}$ \\
\hline
\end{tabular}

* Maximal value obtained during the infusion of each solution. 
follow discontinuation of treatment with steroids. When expansion of ECF was thus maintained, infusion of fructose alone produced rates of $\mathrm{C}_{\mathrm{H}_{2} \mathrm{O}}$ which were equal to, or greater than, those observed in the depleted state during fructose-saline infusions, and in Patient L.G. were greater than those obtained during treatment with cortisol ( Tables I, II, and IV). In Patient A.B. the maximal $\mathrm{C}_{\mathrm{H}_{2} \mathrm{O}}$ with fructose followed by saline was comparable to that with fructose-saline and cortisol. This finding of an impaired free-water clearance, which may be corrected by saline alone, suggests that cortisol-like steroids are not essential for normal renal tubular impermeability to water (1). Furthermore, since saline alone may, in patients with Addison's disease, correct the defect in $\mathrm{C}_{\mathrm{H}_{2} \mathrm{O}}$, this defect cannot be ascribed to inability to adsorb sodium at the site of free water formation in the absence of steroids. The higher $\mathrm{C}_{\mathrm{H}_{2} \mathrm{O}}$ seen in two patients when expansion with saline was supplemented by treatment with cortisol, may be due either to an improved sodium reabsorption (indicated in J.D. by a relatively greater increase in GFR than in sodium excretion), or to a more effective degree of expansion of ECF (indicated in M.T. by a body weight $2.1 \mathrm{~kg}$ higher), or to both.

Thus, in Addison's disease, an expansion of $\mathrm{ECF}$, whether produced acutely or sustained, leads to a water diuresis. Moreover, when ECF is depleted, a rapid infusion of fructose or mannitol, each of which expands body fluid volume transiently, promotes an initial, unsustained $\mathrm{C}_{\mathrm{H}_{2} \mathrm{O}}$ (Tables I and III).

An infusion of saline may increase both GFR (8), and solute excretion, two of the variables important in the formation of solute-free water (9). As previously shown for untreated patients with Addison's disease (10), the GFR was low in these patients when they were not receiving cortisol-like steroids and saline. A reduction in GFR may well contribute to the defective $\mathrm{C}_{\mathrm{H}_{2} \mathrm{O}}$ : acute reduction in GFR can abolish a water diuresis in both $\operatorname{dog}(11)$ and man $(12,13)$. Conversely, the rise in GFR after administration of aminophylline in adrenal insufficiency is accompanied by a rise in $\mathrm{C}_{\mathrm{H}_{2} \mathrm{O}}$ (1). Whereas a higher GFR was usually found together with the improved $\mathrm{C}_{\mathrm{H}_{2} \mathrm{O}}$ after sustained salt loading (compare Tables I and II), $\mathrm{C}_{\mathrm{H}_{2} \mathrm{O}}$ frequently improved be- fore any change in GFR (Figure 1) or with only a small change after acute salt loading (Table I).

A rise in GFR, although small, may contribute to the increase in $\mathrm{C}_{\mathrm{H}_{2} \mathrm{O}}$. Even in the patients who did not show a measurable change in GFR, an increase in renal blood flow could well have occurred during expansion with saline and may have contributed to the increase in $\mathrm{C}_{\mathrm{H}_{2} \mathrm{O}}$.

An improvement of GFR or of renal hemodynamics could increase $\mathrm{C}_{\mathrm{H}_{2} \mathrm{O}}$ by increasing the quantity of sodium reaching the distal tubule. Indeed, the increase in $\mathrm{C}_{\mathrm{H}_{2} \mathrm{O}}$ during infusion of saline was, on occasion, accompanied by an increase in the excretion of sodium. The effect on $\mathrm{C}_{\mathrm{H}_{2} \mathrm{O}}$ of such an increase in excretion of sodium was further explored by infusing hypotonic solutions of mannitol. With mannitol it was possible to produce the largest increases in total solute and sodium excretion with only minimal changes in GFR ( Table III). $\quad \mathrm{C}_{\mathrm{H}_{2} \mathrm{O}}$ rose to rates comparable with those observed when solute excretion was increased by other means (1). Nevertheless, in only one patient (J.D., depleted, Figure 3) was the increased rate of sodium and solute excretion seen with mannitol associated with a $\mathrm{C}_{\mathrm{H}_{2} \mathrm{O}}$ higher than that produced with fructose in a comparable state of expansion. When the patients were in the depleted state an infusion of saline produced a still greater excretion of $\mathrm{C}_{\mathrm{H}_{2} \mathrm{O}}$ but a lesser excretion of sodium and solute than did mannitol. Even during sustained expansion with saline, when mannitol produced the highest $\mathrm{U}_{\mathrm{Na}} \mathrm{V}$ and $\mathrm{U}_{\mathrm{Osm}} \mathrm{V}$ seen (Table III), $\mathrm{C}_{\mathrm{H}_{2} \mathrm{O}}$ was lower than it was during the infusion of saline in Patients A.B. and L.G. when they were depleted (Table I). In contrast, the increase in $\mathrm{C}_{\mathrm{H}_{2} \mathrm{O}}$ during the infusion of saline could occur either before any change, or with only a small change, in $\mathrm{U}_{\mathrm{osm}} \mathrm{V}$ and $\mathrm{U}_{\mathrm{Na}} \mathrm{V}$ (Table $\mathrm{I}$, Figure 1). Indeed, since mannitol is most effective in increasing $\mathrm{C}_{\mathrm{H}_{2} \mathrm{O}}$ in those conditions where relatively greater absorption of sodium in the proximal tubule limits delivery of this ion distally $(14,15)$, it should be less effective in a condition where tubular reabsorption of sodium is reduced. Thus, since increased solute excretion and increased delivery of sodium to distal sites-two factors which mediate effects of GFR on $\mathrm{C}_{\mathrm{H}_{2} \mathrm{O}}$ (9) -produced in our patients only small changes in $\mathrm{C}_{\mathrm{H}_{2} \mathrm{O}}$, it is possible that changes in GFR or in 
solute delivery may not account wholly for the improvement in water excretion with saline.

A third possible effect of saline may be to decrease circulating antidiuretic hormone $(\mathrm{ADH})$. Whereas it is likely that patients with adrenal insufficiency have a normal sensitivity to $\mathrm{ADH}$ and inactivate it at a normal rate (16), saline might still serve to decrease release of the hormone. It has been claimed that increased amounts of antidiuretic substances are present in the serum of adrenalectomized rats (17) and of patients with Addison's disease (18). Moreover, when neurohypophyseal insufficiency complicates adrenal insufficiency, one may find an impairment in the conservation of water (dilute urine associated with hypertonic serum) rather than in its excretion (19) ; serum sodium concentrations do not decrease significantly $(20)$.

In the present studies the rise of urinary osmolalities to 314,445 , and 433 mOsm per L during the infusion of fructose in Patients J.D., L.G., and M.T., respectively, while the volume of ECF was depleted (Table I), may be attributable to an increased secretion of ADH. Although saline could produce $\mathrm{C}_{\mathrm{H}_{2} \mathrm{O}}$ in the presence of small quantities of $\mathrm{ADH}$ by increasing solute excretion (21, 22 ), the relative ineffectiveness of mannitol as well as the frequent increase of $\mathrm{C}_{\mathrm{H}_{2} \mathrm{O}}$ before an increase in $U_{0 s m} V$ suggests that such an effect will not explain the diuresis seen in our studies.

On the other hand, the expansion of ECF volume that is induced by infusion of saline may serve to decrease secretion or release of $A D H$. In normal subjects the infusion of isotonic saline (2) and of iso- and hyperoncotic albumin (3) produces water diuresis without measurably changing GFR or, in the case of albumin, sodium excretion.

Mannitol also may expand ECF and may thereby have produced the increase in $\mathrm{C}_{\mathrm{H}_{2} \mathrm{O}}$. This expansion does not appear to be maintained, however, since both GFR and $\mathrm{C}_{\mathrm{H}_{2} \mathrm{O}}$ fell despite continued infusion of mannitol.

Data suggesting that some function of the volume of the extracellular fluid influences ADH release have recently been reviewed (23). Whereas the pathway by which the volume of body fluid may mediate $\mathrm{ADH}$ release is not known, the vagus nerves do not appear to be necessary (24). If, as suggested, the volume of ECF does play a role in the regulation of $\mathrm{ADH}$ secretion, then the loss of ECF that occurs in untreated Addisonian patients may well contribute to their defect in water excretion. Also, such a mechanism could explain the greater correction of $\mathrm{C}_{\mathrm{H}_{2} \mathrm{O}}$ with expansion of ECF than that usually observed with an increase in GFR and in solute excretion without expansion.

\section{SUMMARY AND CONCLUSIONS}

Free water clearance $\left(\mathrm{C}_{\mathrm{H}_{2} \mathrm{O}}\right)$ was studied in four patients with Addison's disease before and during both acute and sustained expansion of extracellular fluid volume (ECF). Acute expansion of ECF was produced by infusing physiologic saline immediately after an infusion of water (containing a metabolizable hexose); sustained expansion, by infusing physiologic saline for 1 to 3 days prior to an infusion of water. Both acute and sustained expansion led to marked increases in $\mathrm{C}_{\mathrm{H}_{2} \mathrm{O}}$, with values in two patients comparable with those obtained during treatment with cortisol. The rise in $\mathrm{C}_{\mathrm{H}_{2} \mathrm{O}}$ was not always accompanied by a rise in glomerular filtration rate (GFR) or solute excretion. Hypotonic mannitol by vein, before and after sustained expansion, was usually less effective than water.

The data suggest that free water formation does not require steroid-dependent reabsorption of sodium at distal tubular sites.

It is not likely that expansion of the volume of ECF increased $\mathrm{C}_{\mathrm{H}_{2} \mathrm{O}}$ only by increasing GFR or the filtered load of solute. The results may indicate a relationship of some function of the volume of ECF to the release or secretion of antidiuretic hormone.

\section{REFERENCES}

1. Kleeman, C. R., Maxwell, M. H., and Rockney, R. E. Mechanisms of impaired water excretion in adrenal and pituitary insufficiency. I. The role of altered glomerular filtration rate and solute excretion. J. clin. Invest. 1958, 37, 1799.

2. Strauss, M. B., Davis, R. K., Rosenbaum, J. D., and Rossmeisl, E. C. "Water diuresis" produced during recumbency by the intravenous infusion of isotonic saline solution. J. clin. Invest. 1951, 30, 862.

3. Welt, L. G., and Orloff, J. The effects of an increase in plasma volume on the metabolism and excretion of water and electrolytes by normal subjects. J. clin. Invest. 1951, 30, 751. 
4. Gill, J. R., Jr., Gann, D. S., Delea, C. S., and Bartter, F. C. Correction of the defect in water excretion in untreated Addisonian patients by volume expansion alone. Clin. Res. 1959, 7, 254.

5. Walser, M., Davidson, D. G., and Orloff, J. The renal clearance of alkali-stable inulin. J. clin. Invest. $1955,34,1520$.

6. Bowman, R. L., Trantham, H. V., and Caulfield, P. A. An instrument and method for rapid, dependable determination of freezing-point depression. J. Lab. clin. Med. 1954, 43, 310.

7. Wesson, L. G., Jr. Electrolyte excretion studies in the dog. Meth. med Res. 1952, 5, 175.

8. Wesson, L. G., Jr. Glomerular and tubular factors in the renal excretion of sodium chloride. Medicine (Baltimore) 1957, 36, 281.

9. Kleeman, C. R., Epstein, F. H., and White, C. The effect of variations in solute excretion and glomerular filtration on water diuresis. J. clin. Invest. 1956, 35, 749.

10. Smith, H. W. The Kidney: Structure and Function in Health and Disease. New York, Oxford Univ. Press, 1951.

11. Berliner, R. W., and Davidson, D. G. Production of hypertonic urine in the absence of pituitary antidiuretic hormone. J. clin. Invest. 1957, 36, 1416.

12. Bartter, F. C. Unpublished observations.

13. Kleeman, D. R., Maxwell, M. H., and Rockney, R. E. Production of hypertonic urine in humans in the probable absence of antidiuretic hormone (ADH). Proc. Soc. exp. Biol. (N. Y.) 1957, 96, 189.

14. Schedl, H. P., and Bartter, F. C. An explanation for and experimental correction of the abnormal water diuresis in cirrhosis. J. clin. Invest. 1960, 39, 248.

15. Bell, N. H., Schedl, H. P., and Bartter, F. C. An explanation for abnormal water retention and hy- ponatremia in congestive heart failure. Clin. Res. 1960, 8, 226.

16. Kleeman, C. R., Koplowitz, J., Maxwell, M. H., Cutler, R., and Dowling, J. T. Mechanisms of impaired water excretion in adrenal and pituitary insufficiency. II. Interrelationships of adrenal cortical steroids and antidiuretic hormone in normal subjects and in diabetes insipidus. $\mathrm{J}$. clin. Invest. 1960, 39, 1472.

17. Birnie, J. H., Eversole, W. J., Boss, W. R., Osborn, C. M., and Gaunt, R. An antidiuretic substance in the blood of normal and adrenalectomized rats. Endocrinology 1950, 47, 1.

18. Slessor, A. Studies concerning the mechanism of water retention in Addison's disease and in hypopituitarism. J. clin. Endocr. 1951, 11, 700.

19. Leaf, A., Mamby, A. R., Rasmussen, H., and Marasco, J. P. Some hormonal aspects of water excretion in man. J. clin. Invest. 1952, 31, 914.

20. Winter, C. A., Ingram, W. R., and Gross, E. G. Effect of Pitressin injections upon the serum electrolytes and water exchange of cats with diabetes insipidus and adrenal insufficiency. Amer. J. Physiol. 1939, 127, 64.

21. de Wardener, H. E., and del Greco, F. The influence of solute excretion rate on the production of a hypotonic urine in man. Clin. Sci. 1955, 14, 715.

22. Orloff, J., Wagner, H. N., Jr., and Davidson, D. G. The effect of variations in solute excretion and vasopressin dosage on the excretion of water in the dog. J. clin. Invest. 1958, 37, 458.

23. Smith, H. W. Salt and water volume receptors. Amer. J. Med. 1957, 23, 623.

24. Pearce, J. W. The effect of vagotomy and denervation of the carotid sinus on diuresis following plasma volume expansion. Canad. J. Biochem. 1959, 37, 81 . 